\title{
PHYTOTOXIC EFFECTS OF METABOLITES FROM Alternaria euphorbiicola AGAINST ITS HOST PLANT Euphorbia heterophylla
}

\author{
Eduardo Vinícius Vieira Varejão* and Antônio Jacinto Demuner \\ Departamento de Química, Universidade Federal de Viçosa, 36570-000 Viçosa - MG, Brasil \\ Luiz Cláudio de Almeida Barbosa \\ Departamento de Química, Universidade Federal de Minas Gerais, 31270-901 Belo Horizonte - MG, Brasil \\ Robert Weingart Barreto \\ Departamento de Fitopatologia, Universidade Federal de Viçosa, 36570-000 Viçosa - MG, Brasil
}

Recebido em 20/11/12; aceito em 15/2/13; publicado na web em 24/5/13

\begin{abstract}
A bioassay-guided fractionation of culture filtrates of the fungus Alternaria euphorbiicola, a pathogen of the weed Euphorbia heterophylla, led to the isolation of anhydromevalonolactone (1), tyrosol (2), $(R)-(-)$-mevalonolactone (3), and cycloglycylproline (4). When tested on the punctured leaves of the host plant, these compounds produced bleached lesions with dark brown margins at concentrations as low as $80 \mu \mathrm{M}$. When tested on the leaves of other relevant weeds, only cycloglycylproline showed selective activity against $E$. heterophylla. This is the first report on the isolation of phytotoxins from A. euphorbiicola and on the phytotoxicity of anhydromevalonolactone, $(R)-(-)$-mevalonolactone, and cycloglycylproline.
\end{abstract}

Keywords: fungi; phytotoxin; wild poinsettia.

\section{INTRODUCTION}

Surveys for fungal pathogens of wild poinsettia in Brazil and their evaluation as potential mycoherbicides for the management of this weed were initiated in the late 1980s. Among the fungi collected and studied, preliminary results indicate that Alternaria euphorbiicola Simmons \& Engelhard holds great promise for herbicidal control. This fungus was found to cause severe inflorescence necrosis, foliage blight, and stem canker on Euphorbia heterophylla L. ${ }^{1}$

Euphorbia heterophylla (wild poinsettia) is regarded as a major weed in many tropical and subtropical countries, being responsible for substantial agricultural losses in important crops, particularly soybeans and corn. ${ }^{2}$

During early investigation, when A. euphorbiicola was evaluated as a putative mycoherbicide, it was observed that the application of<smiles>CC1=CC(=O)OCC1</smiles>

(1)<smiles>O=C1C[C@H](O)CCO1</smiles>

(3)<smiles>OCCc1ccc(O)cc1</smiles>

(2)

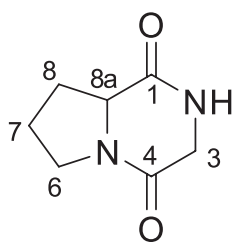

(4)
Figure 1. Chemical structures of the metabolites isolated from A. euphorbiicola

*e-mail: eduardo.varejao@ufv.br fungal spore suspensions on the host plant resulted in the production of widespread necrosis at time intervals ranging from few hours to 1-2 days after application. However, this was regarded as too short a period to allow for the occurrence of the whole process of spore germination, fungal penetration of tissues, colonization of plant organs, and development of symptoms due to plant infection. These observations led to the conjecture that $A$. euphorbiicola might produce phytotoxic metabolites capable of causing the first wave of damage to the host plant.

It is well recognized that phytopathogenic fungi commonly produce toxins that may play a role in plant disease development, adversely affecting their infected hosts. ${ }^{3,4}$ In this paper, we describe the isolation of anhydromevalonolactone (1), tyrosol (2), (R)-(-)-mevalonolactone (3), and cycloglycylproline (4) from A. euphorbiicola and their phytotoxic activity against the host plant wild poinsettia.

\section{EXPERIMENTAL}

\section{Fungal strain, culture media, and growth conditions}

Alternaria euphorbiicola was isolated from naturally infected E. heterophylla plants collected in Viçosa, Minas Gerais State, Brazil. The fungal species was identified by Prof. Robert Weingart Barreto, from the Department of Phytopathology, Universidade Federal de Viçosa (UFV), and stored at $5{ }^{\circ} \mathrm{C}$ in the culture collection Octávio de Almeida Drumond of UFV. The fungus was cultured on general purpose VBA medium ${ }^{5}$ at $25^{\circ} \mathrm{C}$ for 7 days. For the production of phytotoxic metabolites, flasks $(1 \mathrm{~L})$ containing Fries medium ${ }^{6}(300 \mathrm{~mL})$ were seeded with five mycelial discs (10 $\mathrm{mm}$ in diameter) obtained from colonies actively growing on VBA. The cultures were incubated on an orbital shaker at $150 \mathrm{rpm}$ and $25^{\circ} \mathrm{C}$ for 21 days in the dark.

\section{Chemical analysis}

Attenuated Total Reflectance (ATR) Fourier Transform Infrared (FT-IR) was registered on a Varian 600-IR FT-IR spectrometer equipped with a Pike GladiATR accessory. ${ }^{1} \mathrm{H}$ and ${ }^{13} \mathrm{C}$ NMR spectra 
were recorded on a Varian Mercury 300 instrument $(300 \mathrm{MHz}$ and $75 \mathrm{MHz}$, respectively) using $\mathrm{CD}_{3} \mathrm{OD}$ as solvent and tetramethylsilane as reference $(\delta=0)$. Mass spectra were recorded under electron impact $(70 \mathrm{eV})$ using Shimadzu GCMS-QP5050A equipment. Column chromatography (CC) was performed on silica gel 60 (Macherey-Nagel, 0.04-0.063 mm). Analytical and preparative thin layer chromatography (TLC) were performed on silica gel $60 \mathrm{G} \mathrm{F}_{254}$ (Macherey-Nagel, $0.25 \mathrm{~mm}$ ) and Kieselgel $60 \mathrm{G} \mathrm{F}_{254}$ (Merck, $1 \mathrm{~mm}$ ), respectively. The melting point was obtained using a Microquímica MQAPF301 apparatus. Optical rotation, $[\alpha]_{D}$, was measured at 25 ${ }^{\circ} \mathrm{C}$ in chloroform using a Bellingham + Stanley Ltd. manual polarimeter. The identities of the isolated metabolites were confirmed by comparing their spectroscopic data with those of respective synthetic compounds. $d, l$-mevalonolactone and tyrosol were purchased from Sigma Aldrich (Milwaukee, WI, USA) and used without further purification. Anhydromevalonolactone and cycloglycylproline were synthesized using known methodologies. ${ }^{7,8}$

\section{Extraction, purification, and identification of phytotoxins}

At harvest, the mycelium mat was removed by filtration; the culture filtrates $(1.6 \mathrm{~L})$ were assayed for phytotoxic activity and extracted exhaustively with ethyl acetate. The combined organic extracts were dried with $\mathrm{MgSO}_{4}$, filtered, and evaporated under reduced pressure. The red-brown residue (186 mg) thus obtained exhibited phytotoxic activity when assayed on $E$. heterophylla leaves and was fractionated by $\mathrm{CC}$. The column was eluted with a gradient of hexane-ethyl acetate 9:1 (v/v) to 0:1 (v/v) and ethyl acetate-methanol 1:1 (v/v) $(200 \mathrm{~mL}$ each). Fractions 5, 6, 8, and 11 showed phytotoxic activity and were subjected to additional fractionation steps to investigate homogeneity. After removal of the solvent, the residue of fraction $5(28.8 \mathrm{mg})$, eluted with hexane-ethyl acetate $1: 1(\mathrm{v} / \mathrm{v})$, was purified by successive preparative TLC on silica gel [eluent hexane-ethyl acetate $2: 3(\mathrm{v} / \mathrm{v})$ ] to give anhydromevalonolactone (1) $(6.1 \mathrm{mg})$. The residues of fraction 6 (31.1 mg), eluted with hexane-ethyl acetate 2:3 (v/v), were subjected to preparative TLC purification on silica gel [eluent hexane-ethyl acetate $1: 1(\mathrm{v} / \mathrm{v})]$, yielding tyrosol $(2)(6.3 \mathrm{mg})$ as colourless crystals from hexane-ethyl acetate. The residues of fraction $8(24.3 \mathrm{mg})$ from the initial column, eluted with hexane-ethyl acetate 1:4 (v/v), were subjected to successive preparative TLC steps [eluent $\mathrm{CHCl}_{3}$-iso- $\mathrm{PrOH}$ 19:1 (v/v)] to yield $(R)-(-)$-mevalonolactone $(3)(7.9 \mathrm{mg})$ as colourless crystals from hexane-ethyl acetate. The residue of fraction 11 (67.3 $\mathrm{mg}$ ) from the initial column, eluted with ethyl-acetate-methanol 1:1 (v/v), was fractionated on a second column by $\mathrm{CC}$ [eluent $\mathrm{CHCl}_{3}$-isoPrOH 9:1 (v/v)]. Fractions (5 mL each) were collected and pooled on the basis of their TLC profile, yielding 7 homogeneous fractions. The residue of fraction $4\left[R_{\mathrm{f}}=0.26, \mathrm{CHCl}_{3}-i s o-\mathrm{PrOH} 9: 1(\mathrm{v} / \mathrm{v})\right]$ crystallized while drying, providing $5.5 \mathrm{mg}$ of colourless crystals further identified as cycloglycylproline [cyclo(Gly-Pro)] (4). These compounds were identified by comparing their spectroscopic data with those reported in the literature, and identities were confirmed by spectroscopic analysis of the respective synthetic compounds.

Anhydromevalonolactone (1): pale yellow oil; TLC [silica gel, hexane-ethyl acetate 2:3 (v/v)]: $R_{\mathrm{f}}=0.40 ;$ FTIR-ATR $v_{\max } \mathrm{cm}^{-1}: 2908$, $1714,1643,1220,1062 .{ }^{1} \mathrm{H}$ NMR $\left(300 \mathrm{MHz}, \mathrm{CDCl}_{3}\right) \delta 2.01(\mathrm{~m}, 3 \mathrm{H}$, H-7), 2.38 (m, 2H, H-4), 4.38 (t, 2H, $J=6.6 \mathrm{~Hz}, \mathrm{H}-3), 5.82(\mathrm{~m}, 1 \mathrm{H}$, $\mathrm{H}-6) ;{ }^{13} \mathrm{C} \mathrm{NMR}\left(75 \mathrm{MHz}, \mathrm{CDCl}_{3}\right) \delta 23.2(\mathrm{C}-7), 29.4(\mathrm{C}-4), 66.1(\mathrm{C}-$ 3), 116.9 (C-6), 158.1 (C-5), 164.8 (C-1). EIMS, $m / z$ (\%) $112\left[\mathrm{M}^{+}\right]$ (47.9), 82 (100), 67 (6.63), 54 (68.4), 39 (84.4).

Tyrosol (2): colourless crystal; TLC [silica gel, hexane-ethyl acetate $4: 1(\mathrm{v} / \mathrm{v})] R_{\mathrm{f}}=0.24 ; \mathrm{mp} 90-91{ }^{\circ} \mathrm{C}$; FTIR-ATR $v_{\max } \mathrm{cm}^{-1}: 3297$,
$1597,1515,1448,1235,1044 .{ }^{1} \mathrm{H}$ NMR $\left(300 \mathrm{MHz}, \mathrm{CD}_{3} \mathrm{OD}\right) \delta 7.02$ (d, 2H, $J=8.1 \mathrm{~Hz}, \mathrm{H}-3, \mathrm{H}-5), 6.68$ (d, 2H, $J=8.1 \mathrm{~Hz}, \mathrm{H}-2, \mathrm{H}-6)$, $5.48(\mathrm{~s}, 1 \mathrm{H}, \mathrm{OH}), 3.67(\mathrm{t}, 2 \mathrm{H}, J=7.2 \mathrm{~Hz}, \mathrm{H}-8), 2.70$ (t, $2 \mathrm{H}, J=7.2$ $\mathrm{Hz}, \mathrm{H}-7) ;{ }^{13} \mathrm{C}$ NMR (75 MHz, CD $\left.\mathrm{OD}\right) \delta 155.6$ (C-1), 129.8 (C-4), 129.7 (C-3, C-5), 114.9 (C-2, C-6), 63.4 (C-8), 38.2 (C-7). EIMS m/z (\%) $138\left[\mathrm{M}^{+}\right]$(138), 107 (100), 77 (20.8), 51 (8.3), 39 (10.9), 31 (6.4).

(R)-(-)-Mevalonolactone (3): colourless crystal; TLC [silica gel, $\mathrm{CHCl}_{3}$-iso-PrOH 19:1 (v/v)] $R_{\mathrm{f}}=0.26 ;[\alpha]_{\mathrm{D}}^{25}-19.6\left(\mathrm{c} 0.4, \mathrm{CHCl}_{3}\right) ; \mathrm{mp}$ 24-26 ${ }^{\circ} \mathrm{C}$; FTIR-ATR $v_{\max } \mathrm{cm}^{-1}: 3396,1730,1263,1128 ;{ }^{1} \mathrm{H}$ NMR (300 MHz, $\mathrm{CDCl}_{3}$ ) $\delta 1.38$ (s, 3H, H-7), 1.91 (m, 2H, H-4), 2.36 (s, $1 \mathrm{H}, \mathrm{OH}), 2.50$ (d, $J=17.4 \mathrm{~Hz}, 1 \mathrm{H}, \mathrm{H}-6 \mathrm{a}), 2.65$ (d, $J=17.4 \mathrm{~Hz}, 1 \mathrm{H}$, $\mathrm{H}-6 \mathrm{~b}), 4.35$ (m, 1H, H-3a), 4.60 (m, 1H, H-3b); ${ }^{13} \mathrm{C} \mathrm{NMR}(75 \mathrm{MHz}$, $\mathrm{CDCl}_{3}$ ) $\delta 29.9$ (C-7), 36.1 (C-4), 44.9 (C-6), 66.3 (C-3), 68.4 (C-5), 170.9 (C-1). EIMS $\mathrm{m} / \mathrm{z}(\%) 71\left[\mathrm{M}-\mathrm{CH}_{3}-\mathrm{CO}_{2}\right]$ (46.3), 58 (28.7), 43 (100), 31 (6.8).

Cycloglycylproline (4): colourless crystal; TLC [silica gel, $\mathrm{CHCl}_{3}$ iso-PrOH 9:10 (v/v)] $R_{\mathrm{f}}=0.26 ; \mathrm{mp} 216-217^{\circ} \mathrm{C}$; FTIR-ATR $v_{\text {max }} \mathrm{cm}^{-1}$ 3220, 2921, 1643, 1456; ${ }^{1} \mathrm{H}$ NMR $\left(300 \mathrm{MHz}, \mathrm{CDCl}_{3}\right) \delta 6.20(\mathrm{~s}, 1 \mathrm{H}$, NH), 4.19-4.06 (m, 2H, 3-Ha, 8a-H), 3.90 (dd, $J=16.9,4.6 \mathrm{~Hz}, 1 \mathrm{H}$, 3-Hb), 3.70-3.56 (m, 2H, 6-H), 2.48-2.30 (m, 1H, 8-Ha), 2.19-1.82 (m, 3H, 7-H, 8-Hb); ${ }^{13} \mathrm{C} \mathrm{NMR}\left(75 \mathrm{MHz}, \mathrm{CDCl}_{3}\right) \delta 22.4(\mathrm{C}-7), 28.4$ (C-8), 45.3 (C-6), 46.6 (C-3), 58.5 (C-8a), 163.6 (C-4), 169.9 (C-1). EIMS m/z (\%) $155\left[\mathrm{M}^{+}+1\right]$ (4.5), $154\left[\mathrm{M}^{+}\right]$(37.1), 126 (7.6), 111 (70.6), 98 (20.1), 83 (78.9), 70 (53.9), 55 (36.6), 41 (100), 30 (42.6).

\section{Leaf spray assay}

Culture filtrates were assayed for phytotoxic activity by a leaf spray assay. ${ }^{9}$ Fully expanded leaves of young E. heterophylla plants (age, 3 weeks) grown in a greenhouse were sprayed with culture filtrates containing $0.5 \%(\mathrm{v} / \mathrm{v})$ Tween $^{\circledR} 80$, kept in a dew chamber at $28{ }^{\circ} \mathrm{C}$, and observed daily for symptom development. Aqueous $0.5 \%$ $(\mathrm{v} / \mathrm{v})$ Tween ${ }^{\circledR} 80$ was used as a control.

\section{Punctured leaf assay}

The phytotoxic effects of the organic extract, chromatographic fractions, and toxins were assessed by a punctured leaf assay. ${ }^{9}$ Wellexpanded leaves of 3-week-old E. heterophylla plants grown in a greenhouse were punctured (adaxial side) using a sterile fine-pointed needle, and droplets $(10 \mu \mathrm{L})$ of each test solution were deposited on each of these sites ( 2 punctures per leaf, 3 leaves per solution). The organic extract, chromatographic fractions, and pure metabolites were first dissolved in a small amount of dimethyl sulfoxide (DMSO) and then diluted to the desired final concentration with distilled water. At 2\% DMSO concentration, which was devoid of phytotoxicity, the organic extract and chromatographic fractions were assayed at $1 \mathrm{mg}$ $\mathrm{mL}^{-1}$ and pure toxins were tested from $1 \mu \mathrm{M}$ to $10 \mathrm{mM}$. After droplet application, the plants were maintained in the dew chamber at $25^{\circ} \mathrm{C}$ under natural light, and the diameter of the lesions was measured after $72 \mathrm{~h}$. Statistical differences between treatments were determined by one-way analysis of variance and means separated using the least significant difference test $(p<0.05)$. The punctured leaf assay was also utilized to evaluate the phytotoxic effects of the isolated toxins at $1 \mathrm{mM}$ on different weeds, namely Bidens pilosa, B. subalternans, Brachiaria decumbens, Chamaesyce hirta, and Ipomoea grandifolia.

\section{RESULTS AND DISCUSSION}

In the leaf spray assay, culture filtrates were capable of producing yellowing and necrosis on E. heterophylla leaves in $<24 \mathrm{~h}$ after 
application. The filtrates were extracted with ethyl acetate affording a crude organic extract capable of causing yellowing, bleaching, and necrosis on the punctured leaves of the host plant. The extract was subjected to successive CC and TLC, as described in the experimental section, to yield four phytotoxic metabolites. On comparison of their acquired spectroscopic data with literature reports, ${ }^{10-12}$ the compounds were identified as anhydromevalonolactone (1), tyrosol (2), (R)-(-)-mevalonolactone (3), and cycloglycylproline (4) (Figure 1). The identities of the isolated metabolites were also confirmed by comparing their spectroscopic data with those of respective synthetic compounds. Absolute configuration of (3) was determined by comparing its optical rotation $[\alpha]_{\mathrm{D}}$ with data from literature. ${ }^{10}$

In the punctured leaf assay, metabolites (1-4) produced bleached lesions with dark brown margins on the host plant leaves, quite similar to the first symptoms observed after the application of spore suspensions of A. euphorbiicola on E. heterophylla. The minimal concentrations of (1-4) capable of damaging the host plant leaves were $0.08,0.1,0.1$, and $0.08 \mathrm{mM}$, respectively (Figure 2).
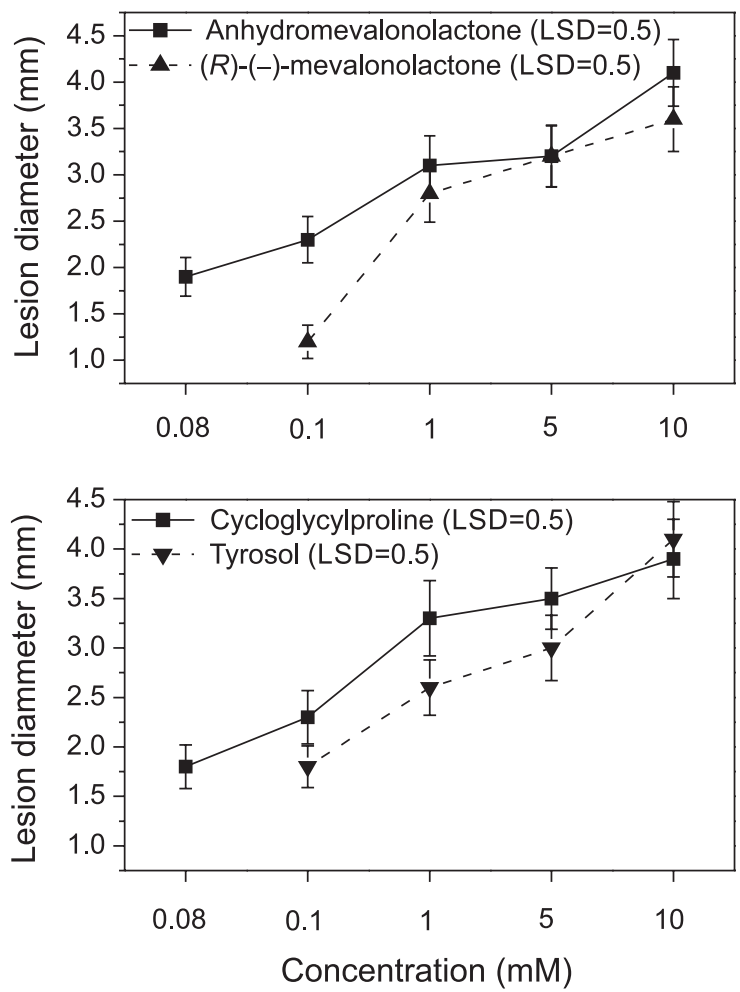

Figure 2. Dose-response relationships for metabolites 1-4 on punctured leaves of E. heterophylla

Tyrosol (2) is a known metabolite produced by various phytopathogenic fungi, and its phytotoxicity is well documented..$^{11,13}$ $(R)$-(-)-mevalonolactone (3) is a terpenoid corresponding to the cyclic form of mevalonic acid, the starting building block of the major biosynthetic route for the synthesis of steroids and terpenes in fungi. ${ }^{14}$ Although this compound has also been isolated from soil and phytopathogenic fungi, ${ }^{15}$ the present paper is the first report of its phytotoxic properties.

Unlike $(R)-(-)$-mevalonolactone $(\mathbf{3})$, we are unaware of any prior reports on the isolation of anhydromevalonolactone (1) from fungi. Because filtrates from A. euphorbiicola culture broth had $\mathrm{pH}$ 5.6, the formation of anhydromevalonolactone in this acidic media by dehydration of $(R)-(-)$-mevalonolactone, rather than being secreted by the fungus, was considered. This possibility was assessed by preparing an aqueous solution of (3) at $3 \mathrm{mg} \mathrm{mL}^{-1}$ and $\mathrm{pH} 5.6$ and monitoring its possible conversion to (1) by gas chromatography-mass spectrometry (GC-MS) analysis. This solution was stirred constantly at room temperature and analyzed at intervals of $0,12,24,48$, and 72 h. After this time had elapsed, the solution was heated at $45^{\circ} \mathrm{C}$ for 8 $\mathrm{h}$ and subjected to additional GC-MS analysis. Because neither the decomposition of (3) nor the formation of (1) was detected during this period, production of (1) by dehydration of (3) at the $\mathrm{pH}$ of the culture broth was disregarded.

Cycloglycylproline (4) is a diketopyperazine also known to be produced by fungal species. ${ }^{12,16}$ Some diketopyperazines are wellknown fungal phytotoxins, ${ }^{17}$ but the phytotoxic properties of cycloglycylproline are first revealed in the present work.

When tested at $0.1 \mathrm{mM}$, anhydromevalonolactone, $(R)-(-)$ mevalonolactone, tyrosol, and cycloglycylproline produced lesions $2.3,1.2,1.8$, and $2.3 \mathrm{~mm}$ in diameter, respectively. At concentrations ranging from $0.1 \mathrm{mM}$ to $0.6 \mathrm{mM}$, degrees of lesions caused by some terpenoids and diketopyperazines obtained from other phytopathogenic fungi in their respective hosts ${ }^{11,17,18}$ are very similar to those observed in the present work. Thus, as considered for those phytotoxins, the phytotoxic metabolites produced by A. euphorbiicola may be, in part, responsible for the virulence of this necrotrophic fungus against $E$. heterophylla. Indeed, it is well recognized that phytotoxic metabolites produced by phytopathogenic fungi often play a key role in infection and virulence. Particularly for necrotrophic fungi, secretion of low-molecular-weight phytotoxins constitutes a strategy to kill plant cells in the initial stages of the interaction and gain access to host nutrients. ${ }^{4}$

The alleged involvement of the metabolites produced by $\mathrm{A}$. euphorbiicola in the early process of invasion of host plant tissues is reinforced by the fast development of lesions (which became evident in $<24 \mathrm{~h}$ after application) produced by these compounds on the host plant leaves and by the similarity between the damage caused by these metabolites and the first symptoms observed after the application of spore suspensions of A. euphorbiicola on E. heterophylla.

Fungal phytotoxins are regarded as a promising source for the discovery of new natural herbicide chemotypes, ${ }^{19,20}$ or at the very least, suggest molecules that could serve as templates in the search for novel synthetic analogs with useful herbicidal action. ${ }^{21,22}$ Because many of these metabolites are non-selective toxins, we decided to evaluate the phytotoxicity of the isolated metabolites against other important weeds by the leaf spray assay (Figure 3).

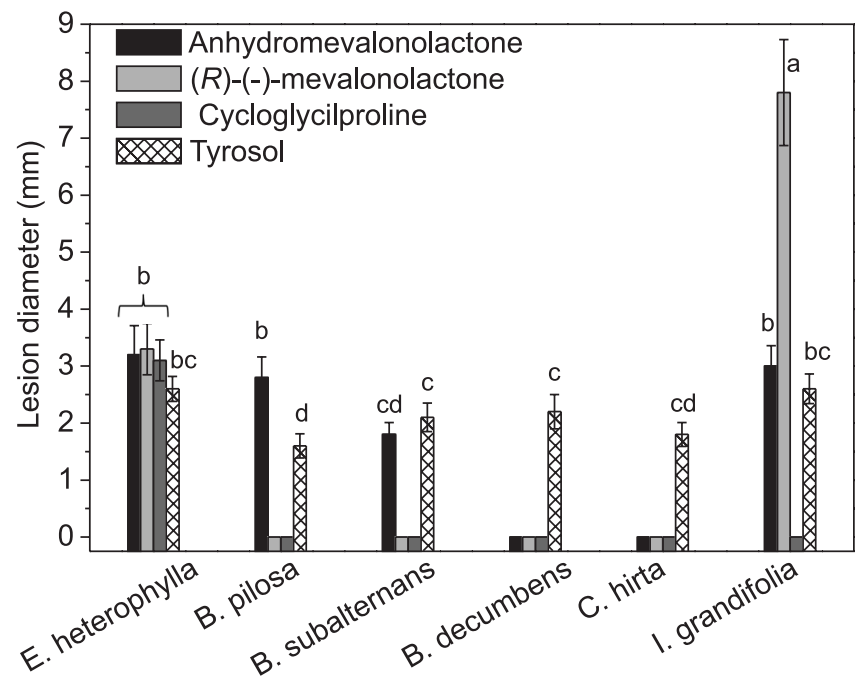

Figure 3. Effects of the metabolites 1-4 (1 mM) on various weed species tested by a punctured leaf assay. Vertical bars represent standard deviation. Means followed by the same did not differ significantly $(p<0.05)$ 
At the concentration tested, $(R)-(-)$-mevalonolactone was active only against $I$. grandifolia, producing bleached lesions with dark brown margins higher than those observed on E. heterophylla leaves. Anhydromevalonolactone and tyrosol showed a wider spectrum of phytotoxicity, and no taxonomic relationship was observed between susceptible or resistant species. Cycloglycylproline did not cause damage in any of these other species, thus presenting selectivity against $E$. heterophylla.

\section{CONCLUSION}

In this study, we report the isolation and identification of phytotoxic metabolites produced by A. euphorbiicola, a pathogen of wild poinsettia. When applied on the punctured leaves of the host plant, $(R)-(-)$-mevalonolactone, anhydromevalonolactone, and cycloglycylproline, whose phytotoxic properties are first revealed herein, and tyrosol, a well-known fungal phytotoxic metabolite, produced bleached lesions with dark brown margins. At the concentrations tested, only cycloglycylproline showed selective phytotoxicity against the host plant. Considering the similarity of the lesions caused by these metabolites with the first symptoms observed after the application of spore suspensions of A. euphorbiicola on E. heterophylla, our findings suggest the participation of these compounds in the early process of invasion of host plant tissue by the fungus.

\section{SUPPLEMENTARY MATERIAL}

Available at http://quimicanova.sbq.org.br, in the form of a PDF file, with free access.

\section{ACKNOWLEDGMENTS}

We acknowledge the following Brazilian Agencies for financial support: Conselho Nacional de Desenvolvimento Científico e Tecnológico (CNPq) and Comissão de Aperfeiçoamento de Pessoal de Nível Superior (CAPES).

\section{REFERENCES}

1. Barreto, R. W.; Evans, H.; Mycopathologia 1998, 36, 21.

2. Willard, T. S.; Griffin, J. L.; Reynolds, D. B.; Saxton, A. M.; Weed Technol. 1994, 8, 679; Webster, T. M.; Nichols, R. L.; Weed Sci. 2012 , 60, 145; Webster, T. M.; Sosnoskie, L. M.; Weed Sci. 2010, 58, 73; Carvalho, L. B.; Bianco, S., Guzzo, C. D.; Planta Daninha 2010, 28, 33.
3. Demuner, A. J.; Barbosa, L. C. A.; Vieira, T. A. M.; Barreto, R. W.; King-Diaz, B.; Lotina-Hennsen, B.; Biochem. Syst. Ecol. 2006, 34, 790.

4. Möbius, N.; Hertweck, C.; Curr. Opin. Plant Biol. 2009, 12, 390; Horbach, R.; Navarro-Quesada, A. R.; Knogge, W.; Deising, H. B.; J. Plant Physiol. 2011, 168, 51.

5. Pereira, J. M.; Barreto, R. W.; Ellison, C.; Maffia, L. A.; Biol. Control 2003, 26, 21.

6. Beadle, G. W.; Tatum, E. L.; Proc. Natl. Acad. Sci. U. S. A. 1941, 27, 499

7. Costa, B. R.; He, X-S.; Linders, J. T. M.; Dominguez, C.; Gu, Z. Q.; Williams, W.; Bowen, W. D.; J. Med. Chem. 1993, 36, 2311.

8. Shintani, R.; Hayashi, T.; Org. Lett. 2011, 13, 350.

9. Pedras, M. S. C.; Ahiahonu, P. W. K.; J. Chem. Ecol. 2004, 30, 2163.

10. Fernandes, R.; Kumar, P.; Tetrahedron: Asymmetry 1999, 10, 4349.

11. Gamboa-Angulo, M. M.; García-Sosa, K.; Alejos-Gonzales, F.; Escalante-Erosa, F.; Delgado-Lamas, G.; Peña-Rodrigues, L. M.; J. Agric. Food Chem. 2001, 49, 1228.

12. Furtado, N. A. J. C.; Pupo, M. T.; Carvalho, I.; Campo, V. L.; Duarte, M. C. T.; Bastos, J. K.; J. Braz. Chem. Soc. 2005, 16, 1448.

13. Evidente, A.; Punzo, B.; Andolfi, A.; Cimmino, A.; Melck, D.; Luque, J.; Phytopathol. Medit. 2010, 49, 74.

14. Hanson J. R.; Chemistry of fungi, Royal Society of Chemistry: Cambridge, 2008.

15. Pittayakhajonwut, P.; Theerasilp, M.; Kongsaeree, P.; Rungrod, A.; Tanticharoen, M.; Thebtaranonth, Y.; Planta Med. 2002, 68, 1017; Ding, L.; Qin, S.; Li, F.; Chi, X.; Laatsch, H.; Curr. Microbiol. 2008, 56, 229; Hemtasin, C.; Kanokmedhakul, S.; Kanokmedhakul, K.; Hahnvajanawong, C.; Soytong, K.; Prabpai, S.; Kongsaeree, P.; J. Nat. Prod. 2011, 74, 609 .

16. Trigos, A.; Reyna, S.; Gutierrez, M. L.; Sanchez, M.; Nat. Prod. Lett. 1997, 11, 13.

17. Stierle, A. C.; Cardellina, J. H.; Strobel, G. A.; Proc. Natl. Acad. Sci. U. S. A. 1998, 85, 8808 .

18. Evidente, A.; Andolfi, A.; Cimmino, A.; Vurro, M.; Fracchiolla, M.; Charudattan, R.; J. Agric. Food Chem. 2006, 54, 1779.

19. Hoagland, R. E.; Weed Technol. 2001, 15, 835.

20. Berestetskiy, O.; Appl. Biochem. Microbiol. 2008, 44, 453.

21. Barbosa, L. C. A.; Demuner, A. J.; Maltha, C. R. A.; Silva, P. S.; Silva, A. A.; Quim. Nova 2003, 26, 655; Barbosa, L. C. A.; Nogueira, L. B.; Maltha, C. R. A.; Teixeira, R. R.; Silva, A. A.; Molecules 2009, 14, 160; Chaves, F. C.; Barbosa, L. C. A.; Demuner, A. J.; Silva, A. A.; Z. Naturforsch., B: J. Chem. Sci. 2006, 61, 1287.

22. Li, Y.; Sun, Z.; Zhuang, X.; Xu, L.; Chen, S.; Li, M.; Crop Prot. 2003, $22,247$. 


\section{PHYTOTOXIC EFFECTS OF METABOLITES FROM Alternaria euphorbiicola AGAINST ITS HOST PLANT}

\section{Euphorbia heterophylla}

Eduardo Vinícius Vieira Varejão* e Antônio Jacinto Demuner

Departamento de Química, Universidade Federal de Viçosa, 36570-000 Viçosa - MG, Brasil

Luiz Cláudio de Almeida Barbosa

Departamento de Química, Universidade Federal de Minas Gerais, 31270-901 Belo Horizonte - MG, Brasil

Robert Weingart Barreto

Departamento de Fitopatologia, Universidade Federal de Viçosa, 36570-000 Viçosa - MG, Brasil

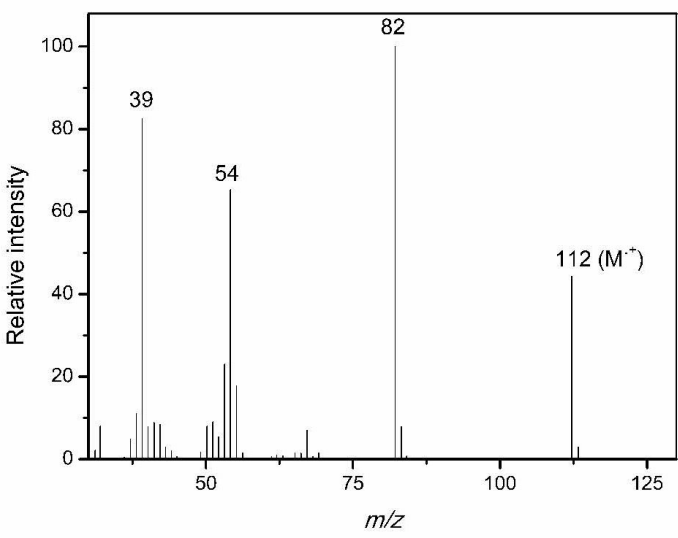

Figure S1. EIMS spectrum (70 eV) of anhydromevalonolactone (1)<smiles>CC1=CC(=O)OCC1</smiles>
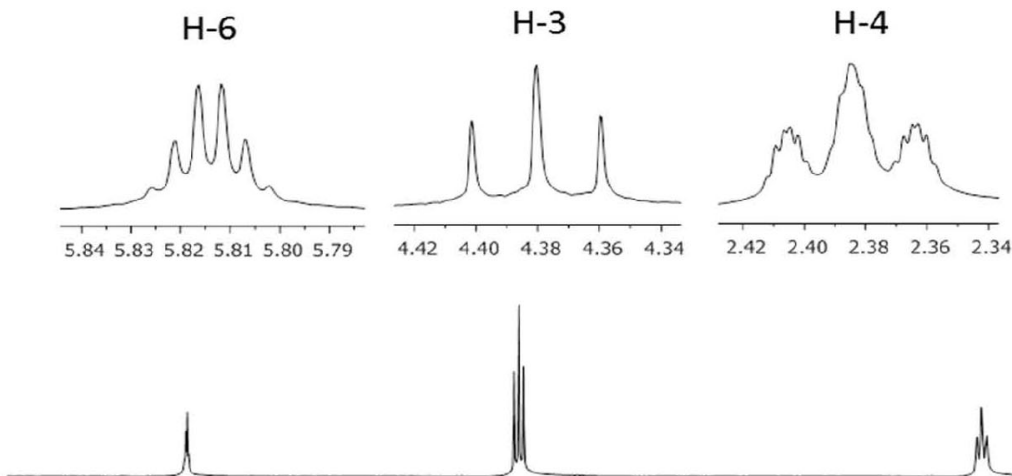

$\begin{array}{llllllllllllllllllllllllllllllllll}6.4 & 6.2 & 6.0 & 5.8 & 5.6 & 5.4 & 5.2 & 5.0 & 4.8 & 4.6 & 4.4 & 4.2 & 4.0 & 3.8 & 3.6 & 3.4 & 3.2 & 3.0 & 2.8 & 2.6 & 2.4 & 2.2 & 2.0 & 1.8 & 1.6 & 1.4 & 1.2 & 1.0 & 0.8\end{array}$

Figure S3. ${ }^{1} \mathrm{H} \mathrm{NMR}$ spectrum (300 $\left.\mathrm{MHz}, \mathrm{CDCl}_{3}\right)$ of anhydromevalonolactone (1)

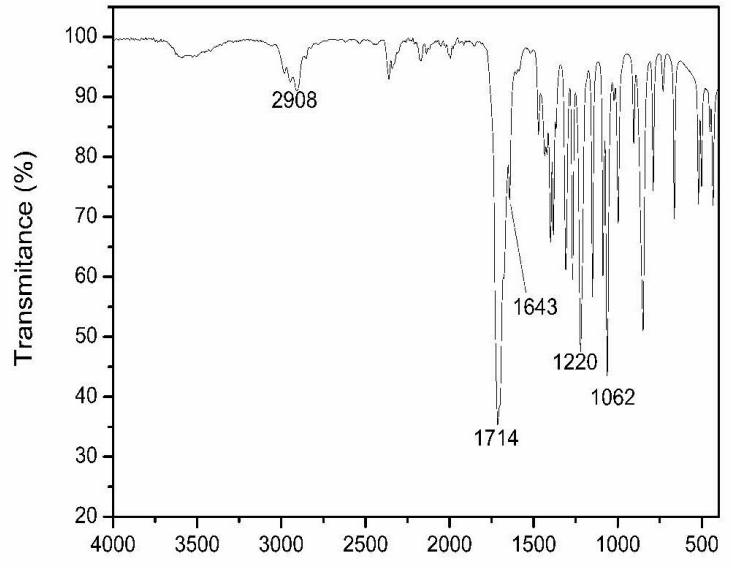

Figure S2. FTIR-ATR spectrum of anhydromevalonolactone (1) 


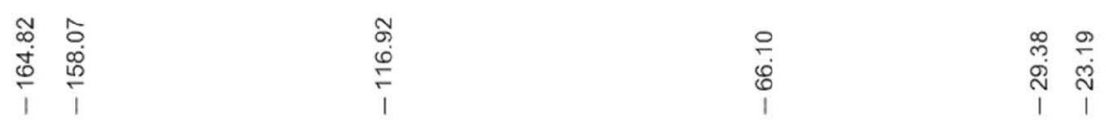<smiles>CC1=CC(=O)OCC1</smiles>

C-3 C-4

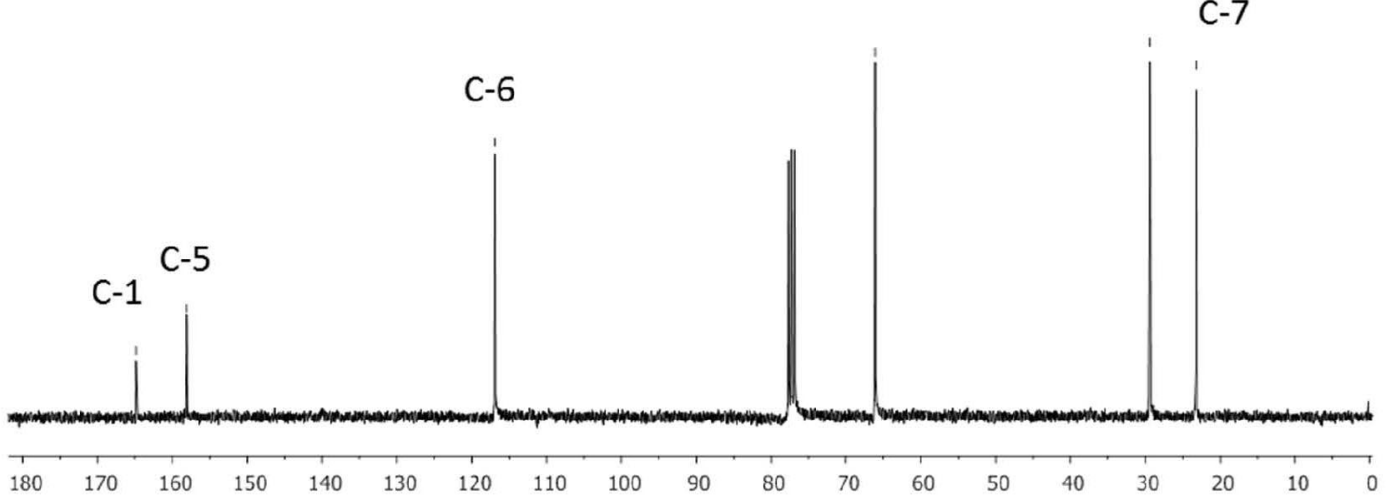

Figure S4. ${ }^{13} \mathrm{C} \mathrm{NMR}$ spectrum $\left(75 \mathrm{MHz}, \mathrm{CDCl}_{3}\right.$ ) of anhydromevalonolactone (1)

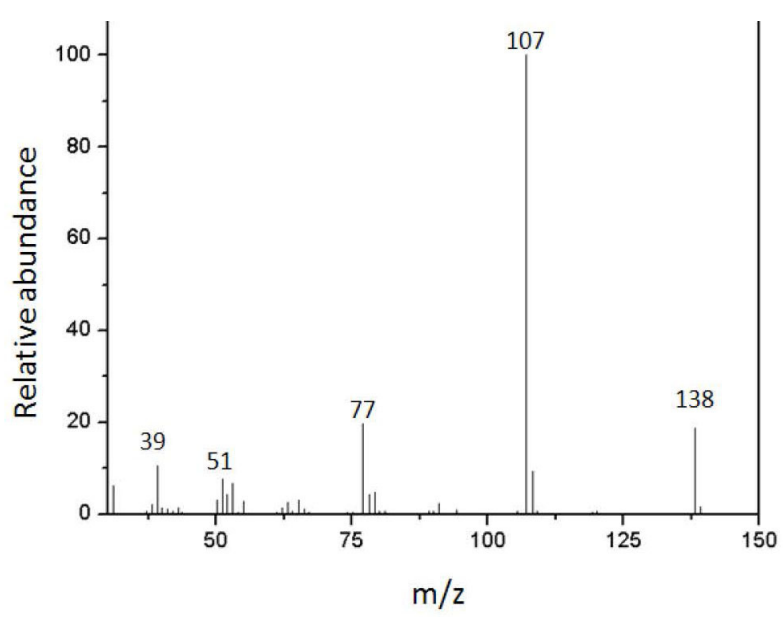

Figure S5. EIMS spectrum (70 eV) of tyrosol (2)

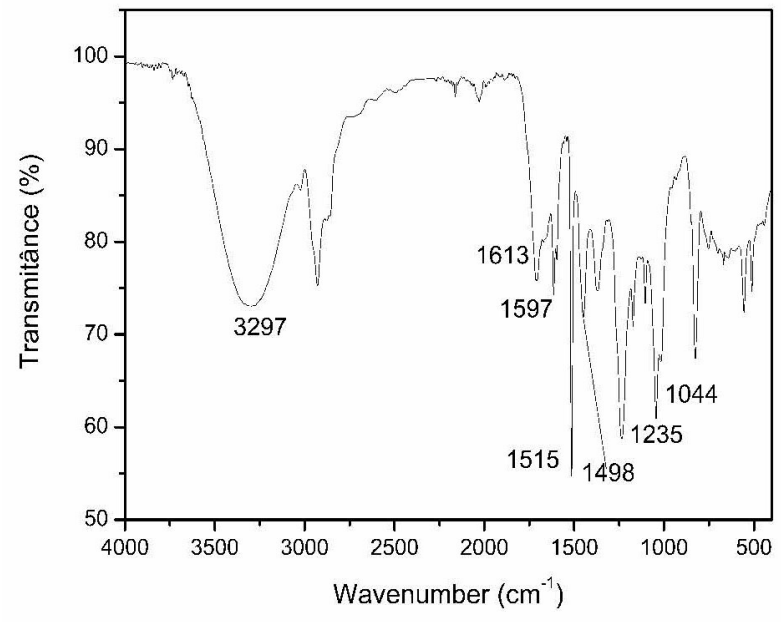

Figure S6. FTIR-ATR spectrum of tyrosol (2) 

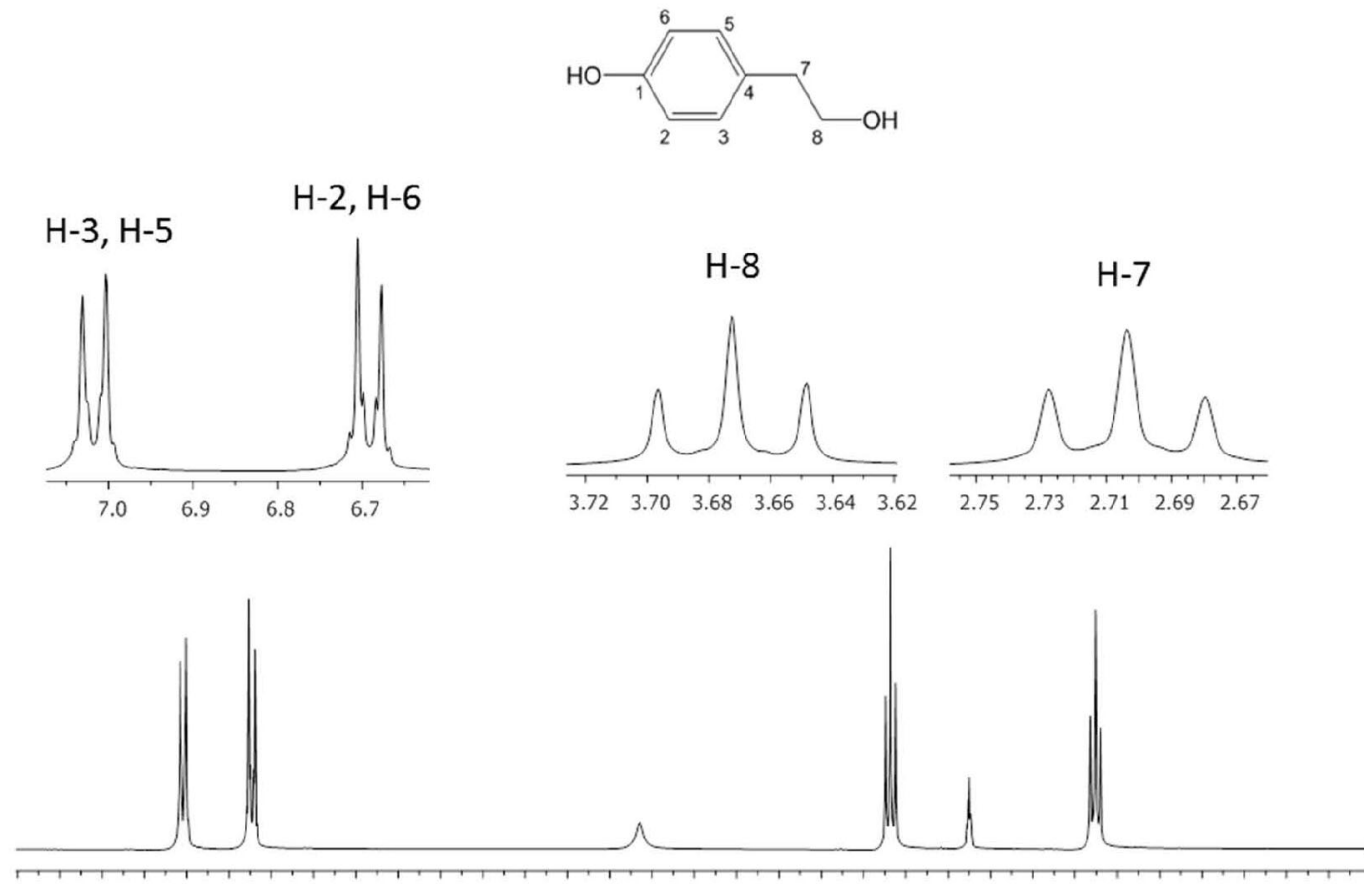

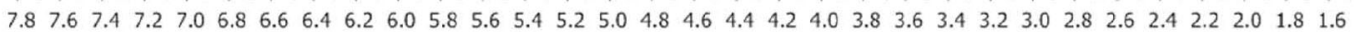

Figure S7. ${ }^{\mathrm{I}} \mathrm{H} \mathrm{NMR}$ spectrum $\left(300 \mathrm{MHz}, \mathrm{CD}_{3} \mathrm{OD}\right)$ of tyrosol (2)
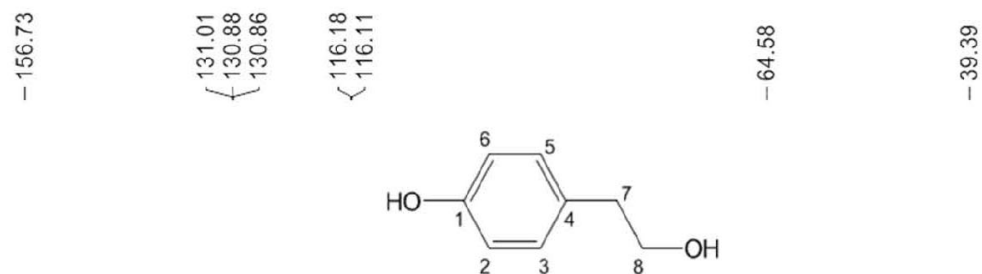

ल)

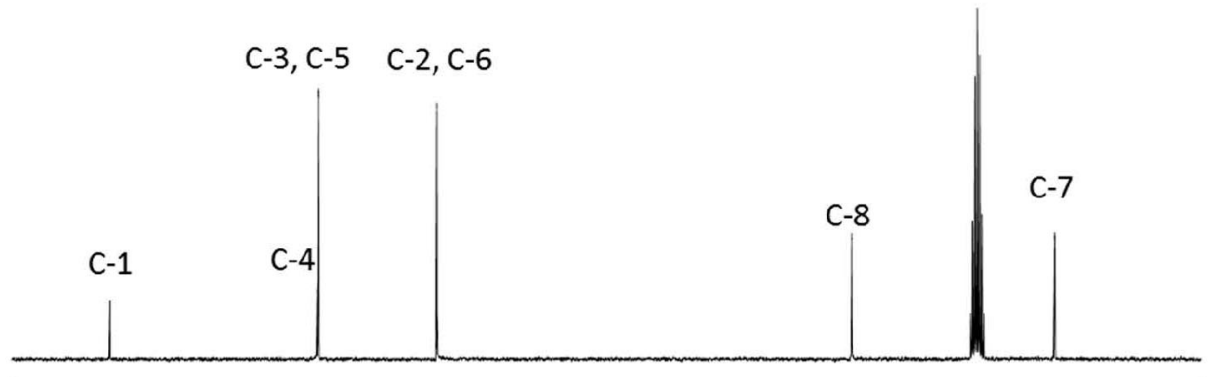

$\begin{array}{llllllllllllllllllllllllllllllll}165 & 160 & 155 & 150 & 145 & 140 & 135 & 130 & 125 & 120 & 115 & 110 & 105 & 100 & 95 & 90 & 85 & 80 & 75 & 70 & 65 & 60 & 55 & 50 & 45 & 40 & 35 & 30 & 25\end{array}$

Figure S8. ${ }^{13} \mathrm{C}$ NMR spectrum ( $75 \mathrm{MHz}, \mathrm{CD}_{3} \mathrm{OD}$ ) of tyrosol (2) 


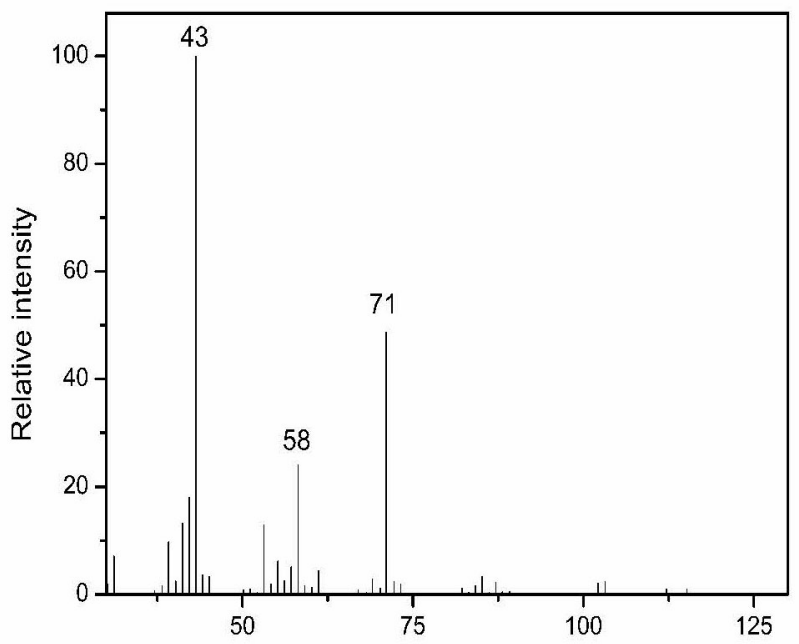

Figure S9. EIMS spectrum (70 eV) of (R)-(-)-mevalonolactone (3)

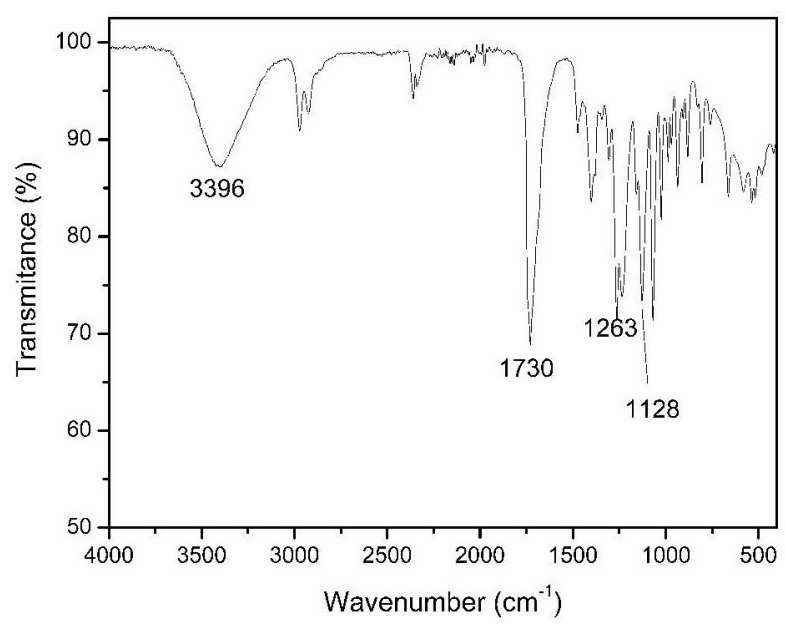

Figure S10. FTIR-ATR spectrum of (R)-(-)-mevalonolactone (3)<smiles>[3H][C@]1(O)[CH]COC(=O)C1</smiles>

H-7

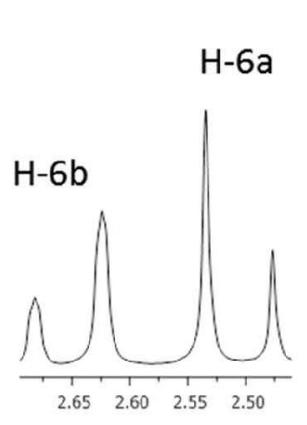

$\mathrm{H}-3 \mathrm{~b} \quad \mathrm{H}-3 \mathrm{a}$

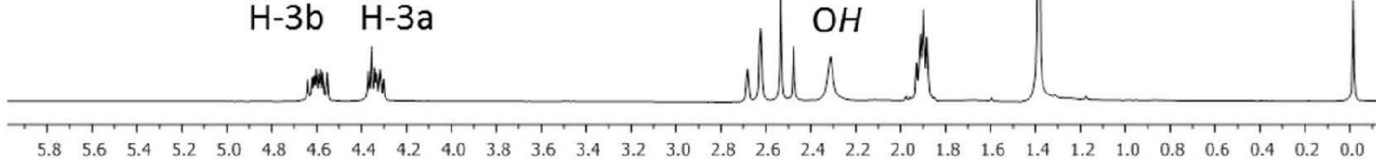

$\mathrm{OH}$

Figure S11. ${ }^{1} \mathrm{H} \mathrm{NMR}$ spectrum (300 $\left.\mathrm{MHz}, \mathrm{CDCl}_{3}\right)$ of $(\mathrm{R})-(-)$-mevalonolactone (3) 


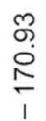

œ 요

$\infty 6$

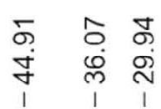<smiles>[3H][C@]1(O)C[CH]OC(=O)C1</smiles>

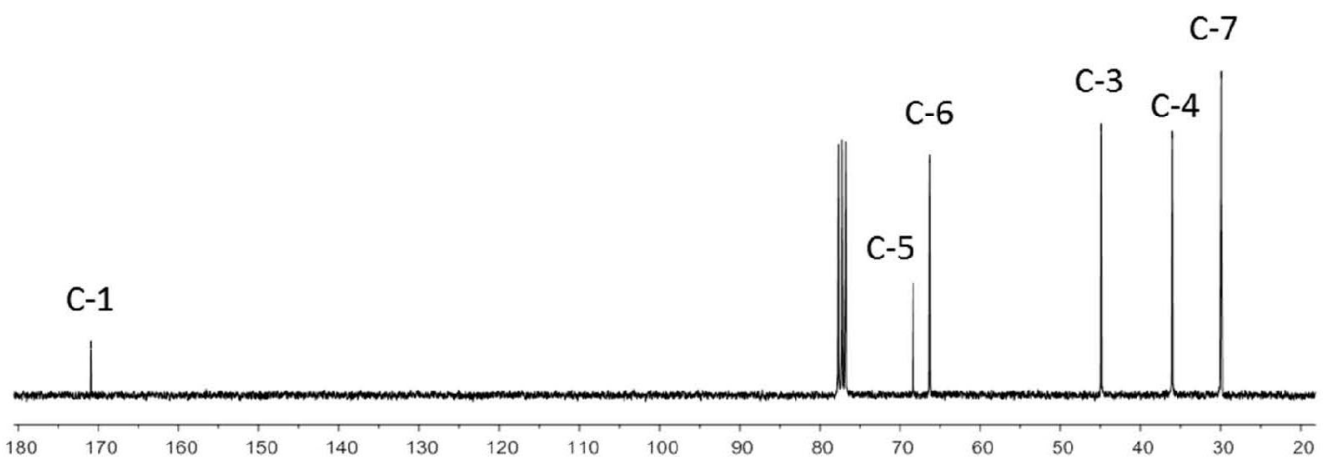

Figure S12. ${ }^{13} \mathrm{C}$ NMR spectrum ( $75 \mathrm{MHz}, \mathrm{CDCl}_{3}$ ) of (R)-(-)-mevalonolactone (3)

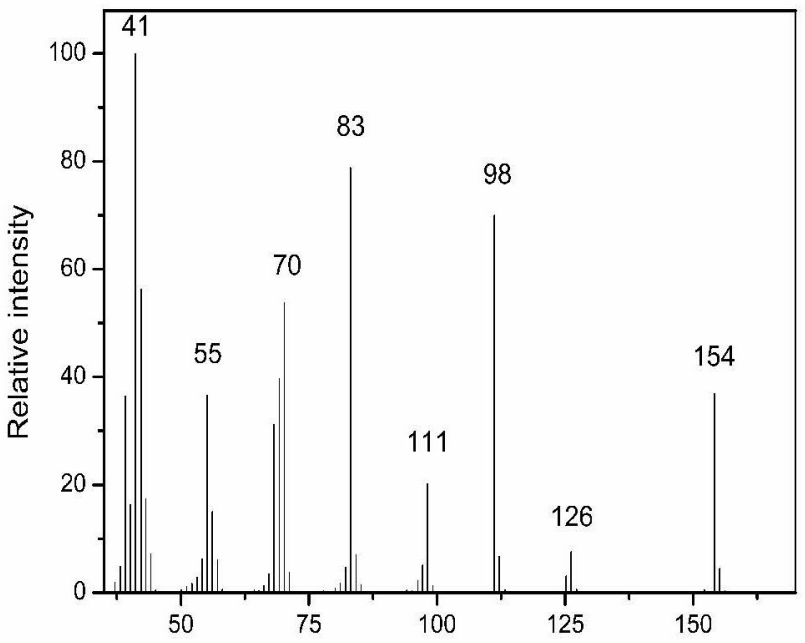

Figure S13. EIMS spectrum (70 eV) of cycloglycylproline (4)

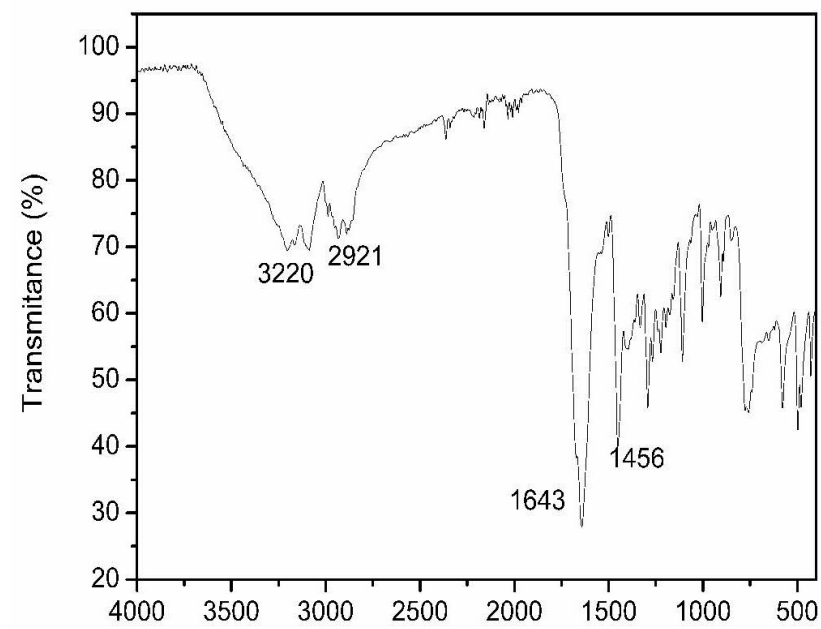

Figure S14. FTIR-ATR spectrum of cycloglycylproline (4) 
<smiles>O=C1CNC(=O)N2CCCC12</smiles>
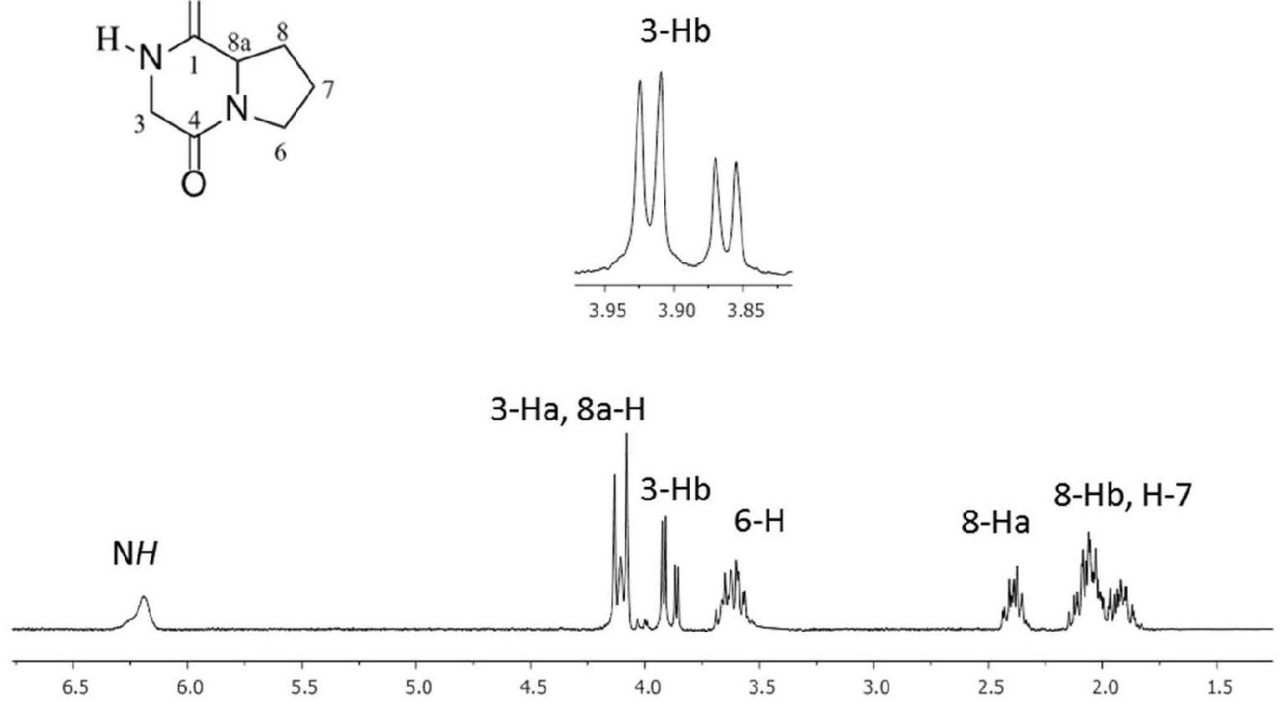

Figure S15. ${ }^{1} \mathrm{H}$ NMR spectrum (300 $\mathrm{MHz}, \mathrm{CDCl}_{3}$ ) of cycloglycylproline (4)

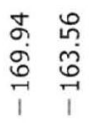<smiles>O=C1NCC(=O)N2CCCC12</smiles>

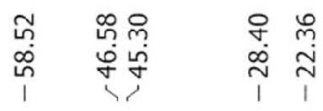

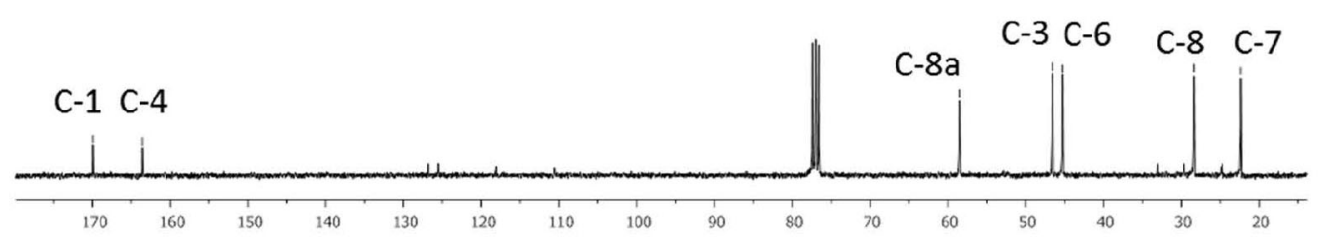

Figure S16. ${ }^{13} \mathrm{C} \mathrm{NMR} \mathrm{spectrum} \mathrm{(75} \mathrm{MHz}_{2} \mathrm{CDCl}_{3}$ ) of cycloglycylproline (4) 

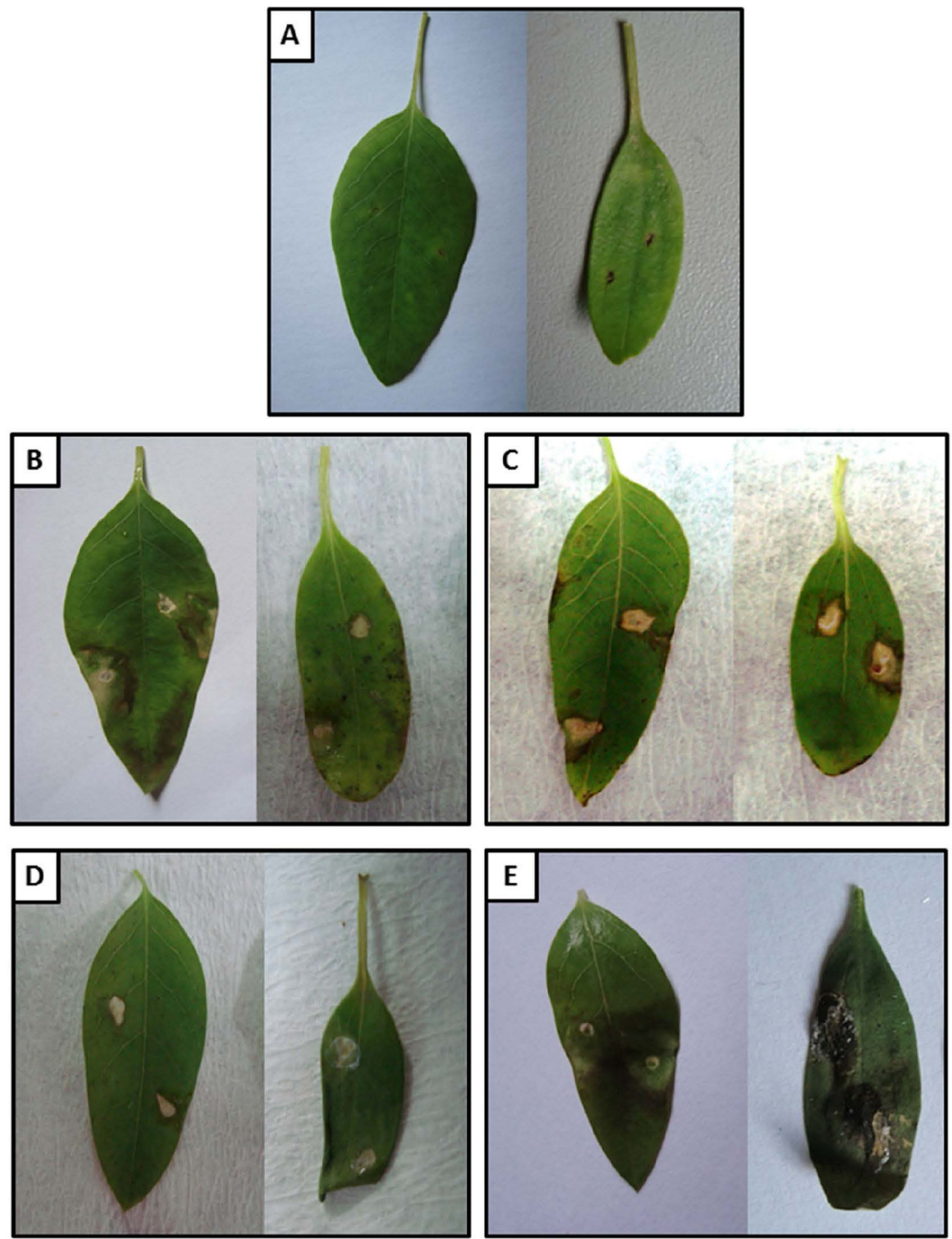

Figure S17. Phytotoxic effects of metabolites $(1 \mathrm{mM})$ from Alternaria euphorbiicola on Euphorbia heterophylla leaves using a leaf spray assay. A) control (2\% DMSO); B) anhydromevalonolactone; C) tyrosol; D) (R)-(-)-mevalonolactone; E) Cycloglycylproline 